\title{
Highly Efficient Red Phosphorescent Osmium(II) Complexes for OLED Applications
}

\author{
Yung-Liang Tung, ${ }^{\dagger}$ Pei-Chi Wu, ${ }^{\dagger}$ Chao-Shiuan Liu, ${ }^{\dagger} \mathrm{Y}$ un $\mathrm{Chi},{ }^{*}{ }^{\dagger} \mathrm{J}$ en-Kan $\mathrm{Yu},{ }^{\ddagger}$ \\ Ya-Hui Hu, ${ }^{\ddagger} \mathrm{Pi}-\mathrm{Tai}$ Chou, ${ }^{*} \neq$ Shie-Ming Peng, ${ }^{\ddagger}$ Gene-H siang Lee, ${ }^{\ddagger}$ Ye Tao, ${ }^{*}, \S$ \\ Arthur J . Carty, ${ }^{\S}$ Ching-Fong Shu, *,ll and Fang-Iy Wull

\begin{abstract}
Department of Chemistry, National Tsing Hua University, 300 Hsinchu, Taiwan,
Department of Chemistry and Instrumentation Center, National Taiwan U niversity,

106 Taipe, Taiwan, Institute for Microstructural Sciences and Steacie Institute for Molecular

Sciences, National Research Council of Canada, Ontario K1A OR6, Canada, and Department of Applied Chemistry, National Chiao Tung University, 300 Hsinchu, Taiwan
\end{abstract}

Received March 11, 2004

Summary: The nonionic, red-emitting complexes [Os$\left.(\mathrm{fppz})_{2} \mathrm{~L}_{2}\right]\left(\mathrm{L}=\mathrm{PPh}_{2} \mathrm{Me}(\mathbf{1}), \mathrm{PPhMe}_{2}(\mathbf{2})\right)$ and [Os(bptz) $\left.{ }_{2} \mathrm{~L}_{2}\right]\left(\mathrm{L}=\mathrm{PPh}_{2} \mathrm{Me}(\mathbf{3})\right.$ ) were synthesized, showing highly intense red phosphorescent emission in $\mathrm{CH}_{2} \mathrm{Cl}_{2}$ solution at $\lambda_{\max } 617,632$, and $649 \mathrm{~nm}$, respectively. The electroluminescent properties of these compounds on OLEDs showed promising device efficiencies required for future OLED applications.

Organometallic complexes containing third-row transition-metal elements are crucial for the fabrication of organic light-emitting diodes (OLEDs). ${ }^{1}$ The strong spin-orbit coupling induced by these heavy-metal ions promotes an efficient intersystem crossing from the singlet to the triplet state, which then facilitates high internal quantum efficiencies ( $\eta_{\text {int }}$ ) for the OLEDs through utilization of both singlet and triplet excitons. As a result, these phosphorescent molecules become increasingly important. With regard to the goal of achieving three primary colors, the design and synthesis of red emitters presents a particular challenge, because their luminescence quantum yield tends to be low due to the smaller energy gap. ${ }^{2}$ Despite this limitation, however, success has been achieved in the preparation of $\operatorname{Ir}(\mathrm{III})^{3}$ and $\mathrm{Pt}(\mathrm{II})^{4}$ red emitters. Recently, some redemitting Os(II) phosphors have begun to receive intensive study. ${ }^{5}$ U nfortunately, because of their ionic nature, these OLED devices suffered inferior performance compared with the neutral Ir(III) counterparts. This is, in

\footnotetext{
$\dagger$ National Tsing Hua University.

₹ National Taiwan University.

$\S$ National Research Council of Canada.

"National Chiao Tung University.

(1) (a) Nazeeruddin, M. K.; Humphry-Baker, R.; Berner, D.; Rivier, S.; Zuppiroli, L.; Graetzel, M. J . Am. Chem. Soc. 2003, 125, 8790. (b) Tamayo, A. B.; Alleyne, B. D.; Djurovich, P. I.; Lamansky, S.; Tsyba, I.; Ho, N. N.; Bau, R.; Thompson, M. E. J . Am. Chem. Soc. 2003, 125 7377. (c) Ostrowski, J. C.; Robinson, M. R.; Heeger, A. J .; Bazan, G. C. Chem. Commun. 2002, 784. (d) Lamansky, S.; Djurovich, P.; Murphy, D.; Abdel-Razzaq, F.; Lee, H.-E.; Adachi, C.; Burrows, P. E.; Forrest, S. R.; Thompson, M. E. J . Am. Chem. Soc. 2001, 123, 4304. (e) Baldo, M. A.; Thompson, M. E.; Forrest, S. R. Pure Appl. Chem. 1999, 71,
} 2095.

(2) (a) Kober, E. M.; Caspar, J . V.; Lumpkin, R. S.; Meyer, T. J . J . Phys. Chem. 1986, 90, 3722. (b) Della Ciana, L.; Dressick, W. J .; Sandrini, D.; Maestri, M.; Ciano, M. Inorg. Chem. 1990, 29, 2792.

(3) (a) Tsuboyama, A.: I wawaki, H.: Furugori, M.; Mukaide, T. Kamatani, J .; I gawa, S.; M oriyama, T.; Miura, S.; Takiguchi, T.; Okada, S.; Hoshino, M.; Ueno, K. J. Am. Chem. Soc. 2003, 125, 12971. (b) Duan, J.-P.; Sun, P.-P.; Cheng, C.-H. Adv. Mater. 2003, 15, 224. (c) Su, Y.-J .; Huang, H.-L.; Li, C.-L.; Chien, C.-H.; Tao, Y.-T.; Chou, P.T.; Datta, S.; Liu, R.-S. Adv. Mater. 2003, 15, 884. (d) Gong, X.; Lim, S.-H.; Ostrowski, J . C.; Moses, D.; Bardeen, C. J .; Bazan, G. C. J . Appl. Phys. 2004, 95, 948. part, attributed to the lack of strong bonding between the cationic emitters and their counteranions within the host matrix. Accordingly, it is proposed that only with the utilization of neutral Os(II) emitters can the goal of practical OLED applications be achieved. In this paper, a new series of such Os(II) emitting complexes are prepared, the molecular structure of which consists of two chelates containing either 3-(trifluoromethyl)-5-(2pyridyl)pyrazole (fppzH) or the corresponding 3-tertbutyl triazole (bptzH), to balance the $2+$ charge on the Os(II) cation, and two phosphine donors located at the trans positions to compl ete the symmetrical octahedral coordination requirement.

Preparation of these Os(II) complexes requires the exploitation of the recently described blue-emitting pyridyl pyrazolate complex $\left[\mathrm{Os}(\mathrm{fppz})_{2}(\mathrm{CO})_{2}\right]$ or its relevant triazolate analogue $\left[\mathrm{Os}(\mathrm{bptz})_{2}(\mathrm{CO})\right]_{2} \cdot{ }^{6}$ The desired synthesis was first initiated by the treatment of $\mathrm{Me}_{3} \mathrm{NO}$ to eliminate the CO ligands, followed by addition of corresponding phosphine ligands. The synthetic scheme

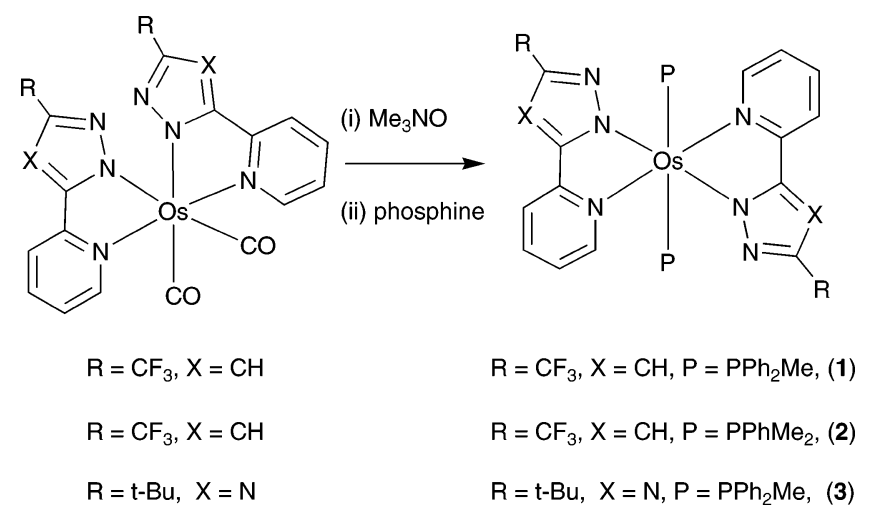

has led to the successful isolation of the red-emitting

(4) (a) Lin, Y.-Y.; Chan, S.-C.; Chan, M. C. W.; Hou, Y.-J ; Zhu, N Che, C.-M.; Liu, Y.; Wang, Y. Chem. Eur. J. 2003, 9, 1263. (b) D'Andrade, B. W.; Brooks, J .; Adamovich, V.; Thompson, M. E.; Forrest, S. R. Adv. Mater. 2002, 14, 1032. (c) Brooks, J ; Babayan, Y.; Lamansky, S.; Djurovich, P. I.; Tsyba, I.; Bau, R.; Thompson, M. E. Inorg. Chem. 2002, 41, 3055. (d) Kavitha, J.; Chang, S.-Y.; Chi, Y.; Yu, J.-K.; Hu, Y.-H.; Chou, P.-T.; Peng, S.-M.; Lee, G.-H.; Tao, Y.-T.; Chien, C.-H.; Carty, A. J . Adv. Functional Mater., in press.

(5) (a) Carlson, B.; Phelan, G. D.; Kaminsky, W.; Dalton, L.; J iang X. Z.; S. L.; J en, A. K.-Y. J. Am. Chem. Soc. 2002, 124, 14162. (b) Bernhard, S.; Gao, X.; Malliaras, G. G.; Abruna, H. D. Adv. Mater. 2002, 14, 433. (c) Kim, J. H.; Liu, M. S.; J en, A. K.-Y.; Carlson, B.; Dalton, L. R.; Shu, C.-F.; Dodda, R. Appl. Phys. Lett. 2003, 83, 776. (d) Ma, Y.; Zhang, H.; Shen, J .; Che, C. Synth. Met. 1998, 94, 245. (e) Gao, F. G.; Bard, A. J . Chem. Mater. 2002, 14, 3465. 


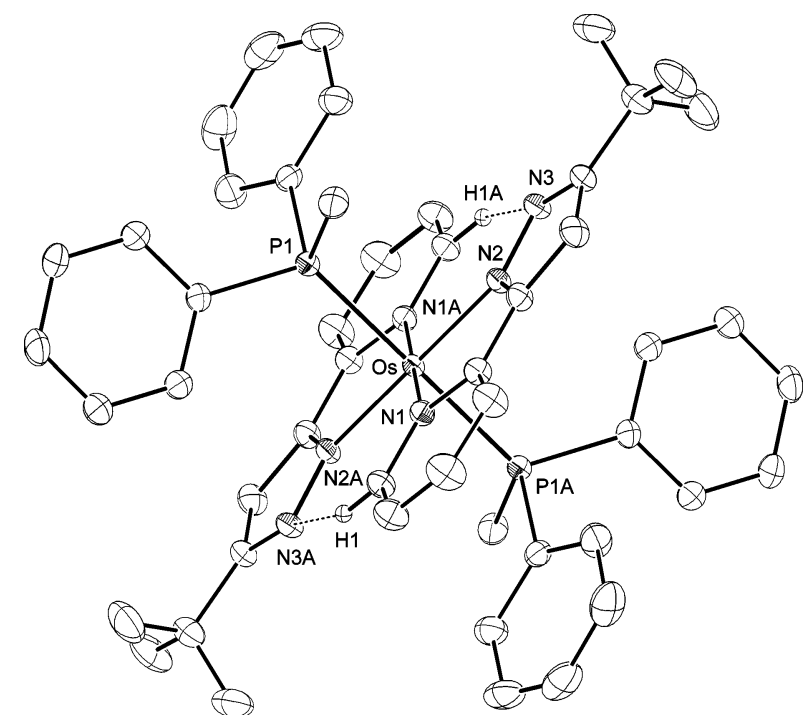

Figure 1. ORTEP diagram of 1. Selected distances $(\AA)$ : Os $-\mathrm{P}(1)=2.3616(5)$, Os $-\mathrm{N}(1)=2.090(2)$, Os $-\mathrm{N}(2)=$ $2.073(2), N(2)-N(3)=1.349(2), N(2)-C(6)=1.352(3)$, $\mathrm{N}(3)-\mathrm{C}(8)=1.355(3)$. Selected angles (deg): $\mathrm{N}(1)-\mathrm{Os}-$ $N(2)=76.48(7), N(1)-O s-N(2 A)=103.52(7)$.

complexes [Os(fppz $\left.)_{2} \mathrm{~L}_{2}\right]\left(\mathrm{L}=\mathrm{PPh}_{2} \mathrm{Me}(\mathbf{1}), \mathrm{PPhMe}_{2}(\mathbf{2})\right)$ and $\left[\mathrm{Os}(\mathrm{bptz})_{2} \mathrm{~L}_{2}\right]\left(\mathrm{L}=\mathrm{PPh}_{2} \mathrm{Me}(\mathbf{3})\right)$ in moderate yields (40-72\%). These Os complexes were fully characterized using routine spectroscopic methods, while complex $\mathbf{1}$ was further examined by single-crystal $X$-ray diffraction analysis.

As depicted in Figure 1, the Os atom of $\mathbf{1}$ is located at a crystallographic center of inversion. The mol ecular frame reveals an octahedral configuration where two chelating fppz ligands establish a nearly planar OsN basal arrangement, together with two $\mathrm{PPh}_{2} \mathrm{Me}$ ligands located at the axial dispositions. The planar ligand arrangement is analogous to that of the porphinato ligand in metalloporphyrins such as [Os(TTP) $\left(\mathrm{PPh}_{3}\right)_{2}$ ] (TTP $=$ meso-tetraphenyl porphinate) and [Os(TPP)(CO)(Im)] (Im = 1-methylimidazole)..$^{7}$ The measured Os$\mathrm{N}(\mathrm{pz})$ distances of $2.073(2) \AA$ in $\mathbf{1}$ are slightly shorter than the respective Os-N (py) bonds of 2.090(2) $\AA$; both lengths fall in the range expected for a typical $\mathrm{N} \rightarrow \mathrm{Os}^{\prime \prime}$ dative bond. Of particular interest are the relatively weak nonbonding contacts (N3A $\cdots \mathrm{C} 1=3.305 \AA$ and $\mathrm{N} 3 \mathrm{~A} \cdots \mathrm{H} 1 \approx 2.50 \AA$ ) observed between the ortho hydrogen atom of the pyridyl moiety and the $\mathrm{N}$ atom of the nearby pyrazolate fragment. In good agreement with this observation, the ${ }^{1} \mathrm{H}$ NMR spectrum revealed a significantly downfield signal at $\delta 10.40$, giving an additional indication of the deshielding effect exerted by the $\mathrm{N}$ atom. It is speculated that this $\mathrm{H}$ bonding, to a certain extent, is akin to that observed in the cobaloxime complexes. ${ }^{8}$

The absorption and luminescence spectra of complexes $\mathbf{1}-\mathbf{3}$ in $\mathrm{CH}_{2} \mathrm{Cl}_{2}$ are shown in Figure 2. The strong absorption bands in the UV region are assigned to the

(6) Wu, P.-C.; Yu, J .-K.; Song, Y.-H.; Chi, Y.; Chou, P.-T.; Peng, S.M.; Lee, G.-H. Organometallics 2003, 22, 4938.

(7) (a) Che, C. M.; Lai, T. F.; Chung, W. C.; Schaefer, W. P.; Gray, H. B. Inorg. Chem. 1987, 26, 3907. (b) Salzmann, R.; Ziegler, C. J .; Godbout, N.; McMahon, M. T.; Suslick, K. S.; Oldfield, E.J . Am. Chem. Soc. 1998, 120, 11323.

(8) Gupta, B. D.; Singh, V.; Yamuna, R.; Barclay, T.; Cordes, W. Organometallics 2003, 22, 2670.

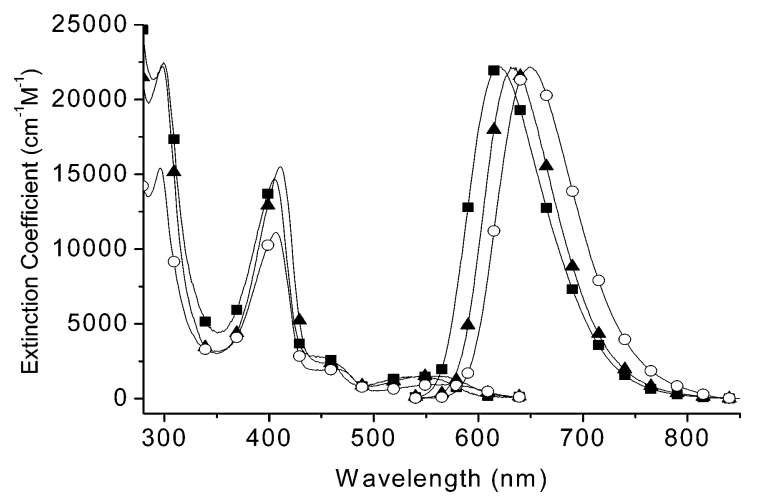

Figure 2. UV-vis absorption and normalized emission spectra of $\mathbf{1}(\boldsymbol{\square}), 2(\mathbf{\Delta})$, and $\mathbf{3}(\mathrm{O})$ in $\mathrm{CH}_{2} \mathrm{Cl}_{2}$ at room temperature.

spin-allowed ${ }^{1} \pi \pi^{*}$ transition of the fppz (or bptz) ligands, owing to their spectral similarity to the free fppz (or bptz) anion. The next lower energy absorption can be ascribed to a typical spin-allowed metal to ligand charge transfer (1MLCT) transition, while two absorption bands extending into the visible region are associated with the spin-orbit coupling enhanced ${ }^{3} \pi \pi^{*}$ and ${ }^{3}$ MLCT transitions. Further luminescence properties (vide infra) support ${ }^{3} \mathrm{MLCT}$ to be in the lowest triplet state with peak wavelengths at $542 \mathrm{~nm}\left(\epsilon=1300 \mathrm{M}^{-1} \mathrm{~cm}^{-1}\right), 553$ $\mathrm{nm}\left(\epsilon=1600 \mathrm{M}^{-1} \mathrm{~cm}^{-1}\right)$, and $560 \mathrm{~nm}\left(\epsilon=950 \mathrm{M}^{-1} \mathrm{~cm}^{-1}\right)$ for complexes $\mathbf{1}-\mathbf{3}$, respectively. It is notable that substitution with strong electron donors such as $\mathrm{PPh}_{2-}$ $\mathrm{Me}$ and $\mathrm{PPhMe}_{2}$ ligands not only increases the entire transition dipole moment but also causes a significant red shift due to the enhancement of dative interactions with Os(II), hence raising the d orbital energy level of the Os metal center. A similar mechanism has been proposed to delineate the el ectron-donating effect for the Os(II) polypyridyl complexes. ${ }^{9}$

Highly intense luminescence was observed for 1-3 with $\lambda_{\max }$ located at 617,632 , and $649 \mathrm{~nm}$, respectively. The entire emission band originating from a triplet state manifold was ascertained by the $\mathrm{O}_{2}$ quenching rate constant of $\sim 1.78 \times 10^{9} \mathrm{M}^{-1} \mathrm{~s}^{-1}$ for $\mathbf{1}-\mathbf{3}$ in $\mathrm{CH}_{2} \mathrm{Cl}_{2}$. The significant overlap of the $0-0$ onsets between emission and the lowest energy absorption band, in combination with a broad, structureless spectral feature, leads us to conclude that the phosphorescence originates primarily from the ${ }^{3} \mathrm{MLCT}$ state. In comparison to $\mathbf{2}$ coordinated with $\mathrm{PPhMe}_{2}$ ligands, complex 1 bearing the $\mathrm{PPh}_{2} \mathrm{Me}$ group reveals a $\sim 15 \mathrm{~nm}$ hypsochromic shift in $\lambda_{\max }$ and can qualitatively be rationalized by a decrease of Os(II) d orbital energy level due to the greater electronwithdrawing strength of an additional phenyl substitution. Table 1 lists the corresponding photophysical data for the studied complexes in both solution and solid phases. The observed lifetimes of ca. $0.6-0.9 \mu \mathrm{s}$ in degassed $\mathrm{CH}_{2} \mathrm{Cl}_{2}$ are considerably shorter than those of most reported red-emitting I $\left(\right.$ III ) complexes. ${ }^{3 a}$ In the solid state, the emission maximum for these osmium phosphors shifts to the red, possibly due to molecular packing, and the lifetime falls within the range of 0.4$0.6 \mu \mathrm{s}$ (Table 1). The emission quantum efficiencies of 1-3 lie within the range $0.19-0.50$ in $\mathrm{CH}_{2} \mathrm{Cl}_{2}$ and $0.1-$

(9) Kober, E. M.; Sullivan, B. P.; Dressick, W. J .; Caspar, J . V.; Meyer, T. J . J . Am. Chem. Soc. 1980, 102, 7383. 
Table 1. Photophysical, Electrochemical, and Device Properties for 1-3

\begin{tabular}{llll}
\hline & \multicolumn{1}{c}{$\mathbf{1}$} & \multicolumn{1}{c}{$\mathbf{2}$} & \multicolumn{1}{c}{$\mathbf{3}$} \\
\hline UV/vis abs $(\mathrm{nm}(\epsilon))^{\mathrm{a}}$ & $405(14700)$ & $411(15500)$ & $406(11100)$ \\
& $454(2400)$ & $456(2600)$ & $466(2000)$ \\
& $542(1300)$ & $553(1600)$ & $560(950)$ \\
$\mathrm{PL} \lambda_{\max }(\mathrm{nm})^{\mathrm{a}}$ & $617(618)$ & $632(655)$ & $649(670)$ \\
$\Phi^{\mathrm{b}}$ & $0.50(0.21)$ & $0.19(0.29)$ & $0.25(0.10)$ \\
$\tau_{\text {obs }}(\mathrm{ns})^{\mathrm{b}}$ & $855(631)$ & $725(610)$ & $634(440)$ \\
$\mathrm{E}_{1 / 2}{ }^{\mathrm{ox}}(\mathrm{V})^{\mathrm{d}}$ & -0.15 & -0.22 & -0.25 \\
$\mathrm{EL}_{\max }(\mathrm{nm})^{\mathrm{c}}$ & 626 & 640 & 658 \\
$\mathrm{~L}_{\max }\left(\mathrm{cd} / \mathrm{m}^{2}\right)^{\mathrm{c}}$ & 3276 & 2155 & 774 \\
$\eta_{\max }(\mathrm{cd} / \mathrm{A})^{\mathrm{c}}$ & $\sim 4.0$ & $\sim 3.0$ & $\sim 1.0$ \\
$\mathrm{~V} @ 1 \mathrm{~cd} / \mathrm{m}^{2}$ & 5.5 & 8.5 & 8.5
\end{tabular}

a Samples were degassed and recorded in $\mathrm{CH}_{2} \mathrm{Cl}_{2}$ at room temperature with $\epsilon$ in $\mathrm{M}^{-1} \mathrm{~cm}^{-1}$. b Data in parentheses are measured in solid state at room temperature. ${ }^{\mathrm{C}}$ OLED device

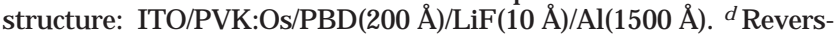
ible oxidation potential referenced to $\mathrm{Fc} / \mathrm{FC}^{+}$.

0.3 in the solid state. The results correlate well with unusually large extinction coefficients measured for the 3 MLCT bands and thus are very desirable for OLEDrelated applications.

The electrochemical behavior of these Os complexes was investigated by cyclic voltammetry using ferrocene as the internal standard. During the anodic scan in $\mathrm{CH}_{2-}$ $\mathrm{Cl}_{2}$, all Os complexes exhibited reversible oxidation with potential in the region -0.15 to $-0.25 \mathrm{~V}$ (Table 1 ). As the oxidation mainly occurs at the Os metal site, ${ }^{10}$ the formal oxidation potential is strongly dependent on the coordination environment of the osmium; i.e., good $\sigma$ donor strength of the ancillary ligand would shift the oxidative potential to a more negative value. This was demonstrated by the fact that replacement of $\mathrm{PPh}_{2} \mathrm{Me}$ ligands by the more electron-donating $\mathrm{PPhMe}_{2}$ decreased the oxidative potential from $-0.15 \mathrm{~V}$ of $\mathbf{1}$ to $-0.22 \mathrm{~V}$ of $\mathbf{2}$, while substitution of the fppz ligands with less electron deficient bptz ligands led to a cathodic shift to $-0.25 \mathrm{~V}$ in $3^{11}$ It is noteworthy that the oxidation potentials of these Os complexes are significantly less than those of ionic Os(II) complexes such as [Os(bpy $)_{2} \mathrm{~L}$ ]$\left(P_{6}\right)_{2}$ (where $L$ is cis-1,2-bis(diphenyl phosphino)ethylene), which has $\mathrm{E}_{1 / 2}{ }^{\mathrm{ox}}=0.87 \mathrm{~V} .{ }^{12}$ The largely cathodic shift of Os complexes $\mathbf{1 - 3}$ is apparently due to their neutral characteristics.

The electroluminescence $(E L)$ spectra of OLE Ds based on $\mathbf{1 - 3}$ are shown in Figure S1 of the Supporting Information. The energy transfer from the host material PVK to the Os(II) emitters is very efficient, as supported by the lack of any PVK emission in the EL spectra. The $E L$ spectra remained unchanged over a wide range of bias voltages. The OLEDs with 1 reached a maximum efficiency $\left(\eta_{\max }\right)$ of $3.9 \mathrm{~cd} / \mathrm{A}$ at a driving voltage of $13 \mathrm{~V}$ with a luminance of $412 \mathrm{~cd} / \mathrm{m}^{2}$. The $\eta_{\max }$ of 2 reached $3.0 \mathrm{~cd} / \mathrm{A}$ at $21 \mathrm{~V}$ with a luminance of $615 \mathrm{~cd} / \mathrm{m}^{2}$, while that of 3 was $1.0 \mathrm{~cd} / \mathrm{A}$ at $20 \mathrm{~V}$ and $271 \mathrm{~cd} / \mathrm{m}^{2}$. Although $\eta_{\max }$ and maximum luminance values of $\mathbf{3}$ appeared to be lower (Table 1), the quantum efficiencies and optical power output of these three compounds are similar,

(10) Abruña, H. D. J . Electrochem. Soc. 1985, 132, 842

(11) The two heterocyclic chelates fppz and bptz exhibit irreversible reduction peak potentials at -2.70 and $-2.73 \mathrm{~V}$, respectively, relative to the ferrocene standard.

(12) The oxidation potential of $\left[\mathrm{Os}(\mathrm{bpy})_{2} \mathrm{~L}\right]\left(\mathrm{PF}_{6}\right)_{2}$ was $+1.38 \mathrm{~V}$ vs SSCE as reported in refs $5 \mathrm{~b}$ and 10 , which can be converted to a value of $+0.87 \mathrm{~V}$ relative to the ferrocene standard. consi dering the fact that the normalized photopic vision functions $\mathrm{V}(\lambda)$ at 630,640 , and $660 \mathrm{~nm}$ are $0.265,0.175$, and 0.061 , respectively. We believe that the turn-on voltages can be significantly reduced by using either a host material with better charge carrier transport properties or a lower work-function cathode, such as Ca or Mg:Ag alloy.

In summary, we have demonstrated the synthesis, spectral and electrochemical properties, and OLED applications of a series of neutral red-emitting Os(II) complexes. In contrast to most previously reported Os(II) red emitters with ionic character, in which the diffusion of the counteranions might seriously deteriorate the device performance, this new series of compl exes comprises discrete, neutral molecules that would remain at their fixed positions upon electron and hole injection. Moreover, the higher HOMO level at the Os(II) center, which is induced by the superior donor ability of anionic fppz (or bptz), may also contribute to more efficient energy transfer and carrier trapping, ${ }^{13}$ giving additional advantages to the overall device efficiency for complexes 1-3. F uture focuses on fabricating the OLED devices via direct deposition as well as functionalizing Os(II) complexes to fine-tune both device color and efficiency should stimulate a broad spectrum of interests in the field of OLED.

\section{Experimental Section}

General Experiments. All reactions were performed under nitrogen. Solvents were distilled from appropriate drying agents prior to use. Commercially available reagents were used without further purification unless otherwise stated. All reactions were monitored by TLC with Merck precoated glass plates $\left(0.20 \mathrm{~mm}\right.$ with fluorescent indicator $\left.U V_{254}\right)$. Flash col umn chromatography was carried out using silica gel from Merck (230-400 mesh). Mass spectra were obtained on a J EOL SX-102A instrument operating in electron impact (EI) mode or fast atom bombardment (FAB) mode. ${ }^{1} \mathrm{H}$ and ${ }^{13} \mathrm{C} N \mathrm{NR}$ spectra were recorded on Varian Mercury-400 and INOVA500 instruments; chemical shifts are quoted with respect to the internal standard tetramethylsilane for ${ }^{1} \mathrm{H}$ and ${ }^{13} \mathrm{C}$ NMR data.

Preparation of 1. Freshly sublimed $\mathrm{Me}_{3} \mathrm{NO}(90 \mathrm{mg}, 1.19$ $\mathrm{mmol})$ was first dissolved in acetonitrile $(5 \mathrm{~mL})$, and the resulting solution was added dropwise to a stirred suspension of $\left[\mathrm{Os}(\mathrm{fppz})_{2}(\mathrm{CO})_{2}\right](200 \mathrm{mg}, 0.25 \mathrm{mmol})$ in toluene $(30 \mathrm{~mL})$, giving a clear, yellow orange solution after stirring for $2 \mathrm{~min}$ at room temperature. The phosphine ligand $\mathrm{PPh}_{2} \mathrm{Me}(567 \mu \mathrm{L}$, $3.0 \mathrm{mmol}$ ) was then added, and the mixture was brought to reflux for $3 \mathrm{~h}$, during which time the col or was found to change to bright red. The reaction was then stopped, toluene solvent and excess phosphine ligand were removed under vacuum, the solid residue was dissolved in $50 \mathrm{~mL}$ of ethyl acetate, and this solution was washed with distilled water $(30 \mathrm{~mL} \times 2)$ to remove the remaining $\mathrm{Me}_{3} \mathrm{NO}$. The organic phase was dried over $\mathrm{Na}_{2} \mathrm{SO}_{4}$, and the solvent was removed in vacuo to yield red-orange crude product. Further purification was conducted by silica gel column chromatography using a 1:1 mixture of ethyl acetate and hexane, followed by recrystallization from $\mathrm{CH}_{2} \mathrm{Cl}_{2}$ and hexane, giving a red-orange crystall ine solid (180 $\mathrm{mg}, 0.18 \mathrm{mmol}$ ); yield $72 \%$. Complexes $\mathbf{2}$ and $\mathbf{3}$ were prepared in an analogous manner.

Spectral data of $\mathbf{1}$ are as follows. MS (EI, ${ }^{192} \mathrm{Os;}$ observed $\mathrm{m} / \mathrm{z}$ [assignment]): $1015\left[\mathrm{M}^{+}\right], 814\left[\mathrm{M}^{+}-\mathrm{PPh}_{2} \mathrm{Me}\right], 614\left[\mathrm{M}^{+}\right.$ - 2PPh ${ }_{2} \mathrm{Me}$. ${ }^{1} \mathrm{H}$ NMR (400 MHz, $\mathrm{d}_{6}$-acetone): $\delta 10.40$ (d, 2H,

(13) J iang, X.; J en, A. K. Y.; Carlson, B.; Dalton, L. R. Appl. Phys. Lett. 2002, 81, 3125 . 
$\left.\mathrm{J}_{H H}=6.0 \mathrm{~Hz}, \mathrm{H}_{\mathrm{py}}\right), 7.32\left(\mathrm{ddd}, 2 \mathrm{H}, \mathrm{J}_{\mathrm{HH}}=7.6,6.0,1.2 \mathrm{~Hz}, \mathrm{H}_{\mathrm{py}}\right)$, 7.15-6.84 (m, 20H, $\left.\mathrm{H}_{\mathrm{py}}, \mathrm{H}_{\mathrm{Ph}}\right), 6.73\left(\mathrm{~s}, 2 \mathrm{H}, \mathrm{H}_{\mathrm{pz}}\right), 6.66-6.14(\mathrm{~m}$, $\left.4 \mathrm{H}, \mathrm{H}_{\mathrm{Ph}}\right), 1.16(\mathrm{t}, 6 \mathrm{H}, \mathrm{J}$ нP $=3.2 \mathrm{~Hz}, \mathrm{Me}) .{ }^{19} \mathrm{~F} \mathrm{NMR}(470 \mathrm{MHz}$, $\mathrm{d}_{6}$-acetone): $\delta-59.8$ (s). ${ }^{31} \mathrm{P}$ NMR (202 MHz, $\mathrm{d}_{6}$-acetone): $\delta$ -17.4 (s). Anal. Calcd for $\mathrm{C}_{44} \mathrm{H}_{36} \mathrm{~F}_{6} \mathrm{~N}_{6} \mathrm{P}_{2} \mathrm{Os}$ : C, 52.07; N, 8.28; $\mathrm{H}$, 3.58. Found: C, 51.99; N, 8.17; H, 3.78.

Spectral data of $\mathbf{2}$ are as follows. MS (FAB, ${ }^{192} \mathrm{Os}$; observed $\mathrm{m} / \mathrm{z}$ [assignment]): $892\left[\mathrm{M}^{+}\right], 754\left[\mathrm{M}^{+}-\mathrm{PPhMe}_{2}\right], 616\left[\mathrm{M}^{+}-\right.$ 2PPhMe ${ }^{2}$. ${ }^{1} \mathrm{H}$ NMR (400 M Hz, $\mathrm{d}_{6}$-acetone): $\delta 10.31$ (dd, 2H, J $\left.\mathrm{HH}=6.6,0.8 \mathrm{~Hz}, \mathrm{H}_{\mathrm{py}}\right), 7.56-7.48\left(\mathrm{~m}, 4 \mathrm{H}, \mathrm{H}_{\mathrm{py}}\right), 7.05(\mathrm{ddd}, 2 \mathrm{H}$, $\left.\mathrm{J}_{H H}=6.8,6.6,0.8 \mathrm{~Hz}, \mathrm{H}_{\mathrm{py}}\right), 6.94-6.87\left(\mathrm{~m}, 8 \mathrm{H}, \mathrm{H}_{\mathrm{Ph}}, \mathrm{H}_{\mathrm{pz}}\right), 6.42-$ $6.38\left(\mathrm{~m}, 4 \mathrm{H}, \mathrm{H}_{\mathrm{Ph}}\right), 0.80(\mathrm{t}, 6 \mathrm{H}, \mathrm{J} \mathrm{HP}=3.6 \mathrm{~Hz}, \mathrm{Me}), 0.60(\mathrm{t}, 6 \mathrm{H}$, $\left.\mathrm{J}_{\mathrm{HP}}=3.6 \mathrm{~Hz}, \mathrm{Me}\right) .{ }^{19} \mathrm{~F}$ NMR $\left(470 \mathrm{MHz}, \mathrm{d}_{6}\right.$-acetone): $\delta-59.5$ (s). ${ }^{31} \mathrm{P}$ NMR (202 M Hz, $\mathrm{d}_{6}$-acetone): $\delta-19.6$ (s). Anal. Calcd for $\mathrm{C}_{34} \mathrm{H}_{32} \mathrm{~F}_{6} \mathrm{~N}_{6} \mathrm{P}_{2} \mathrm{Os}: \mathrm{C}, 45.84 ; \mathrm{N}, 9.43 ; \mathrm{H}, 3.62$. Found: $\mathrm{C}$, 46.00; N, 9.32; H, 3.81.

Spectral data of $\mathbf{3}$ are as follows. MS (FAB, 192Os; observed $\mathrm{m} / \mathrm{z}$ [assignment]): $994\left[\mathrm{M}^{+}\right], 794\left[\mathrm{M}^{+}-\mathrm{PPh}_{2} \mathrm{Me}\right.$ ], $594\left[\mathrm{M}^{+}-\right.$ 2PPh ${ }_{2} \mathrm{Me}$ ]. ${ }^{1} \mathrm{H} N M R\left(500 \mathrm{MHz}, \mathrm{d}_{4}\right.$-methanol): $\delta 10.37$ (d, 2H, $\left.\mathrm{J}_{\mathrm{HH}}=4.8 \mathrm{~Hz}, \mathrm{H}_{\mathrm{py}}\right), 7.34\left(\mathrm{~d}, 4 \mathrm{H}\right.$, J $\left.\mathrm{HH}=4.8 \mathrm{~Hz}, \mathrm{H}_{\mathrm{py}}\right), 7.09-6.86$ $\left(\mathrm{m}, 18 \mathrm{H}, \mathrm{H}_{\mathrm{py}}, \mathrm{H}_{\mathrm{Ph}}\right), 6.62-6.59\left(\mathrm{~m}, 4 \mathrm{H}, \mathrm{H}_{\mathrm{Ph}}\right), 1.63(\mathrm{~s}, 18 \mathrm{H}, \mathrm{t} \mathrm{Bu})$, 0.90 (s, br, 6H, Me). ${ }^{31} \mathrm{P} \mathrm{NMR}\left(202 \mathrm{MHz}, \mathrm{d}_{4}\right.$-methanol): $\delta-19.6$ (s). Anal. Calcd for $\mathrm{C}_{48} \mathrm{H}_{52} \mathrm{~N}_{8} \mathrm{P}_{2} \mathrm{Os}$ : C, 58.05; N, 11.28; $\mathrm{H}, 5.28$. Found: C, 57.71; N, 11.43; H, 5.40.

X-ray Structural Analysis. Single-crystal X-ray diffraction data of $\mathbf{1}$ were measured on a Bruker SMART CCD diffractometer using $\lambda(\mathrm{MoK} \alpha)$ radiation $(\lambda=0.71073 \AA)$. The data collection was executed using the SMART program. Cell refinement and data reduction were carried out with the SAINT program. The structure was determined using the SHELXTL/PC program and refined using full-matrix least squares. All non-hydrogen atoms were refined anisotropically, whereas hydrogen atoms were placed at calculated positions and included in the final stage of refinements with fixed parameters.

Selected crystal data of 1: $\mathrm{C}_{44} \mathrm{H}_{36} \mathrm{~F}_{6} \mathrm{~N}_{6} \mathrm{OsP}_{2}, \mathrm{M}_{\mathrm{r}}=1014.93$, triclinic, space group $\mathrm{P} \overline{1}, \mathrm{a}=10.4469(5) \AA, b=10.5233(6) \AA$, $\mathrm{C}=10.6829(6) \AA, \alpha=71.968(1)^{\circ}, \beta=62.053(1)^{\circ}, \gamma=82.167(1)^{\circ}$, $\mathrm{V}=986.46(9) \AA^{3}, \mathrm{Z}=1, \rho_{\text {calcd }}=1.708 \mathrm{~g} \mathrm{~cm}^{-3}, \mathrm{~F}(000)=502$, crystal size $0.35 \times 0.30 \times 0.25 \mathrm{~mm}, \lambda($ MoK $\alpha)=0.7107 \AA, \mathrm{T}=$ $295 \mathrm{~K}, \mu=3.383 \mathrm{~mm}^{-1}, 4516$ reflections collected $\left(R_{\text {int }}=\right.$ 0.0253 ), final $\operatorname{R} 1(I>2 \sigma(I))=0.0182$, wR2(all data) $=0.0438$.

Acknowledgment. We thank the National Science Council of Taiwan for financial support (Grant Nos. NSC 91-2119-M-002-016 and NSC 91-2113-M-007-006).

Supporting Information Available: Text giving experimental procedures involving photophysical and electrochemical data and OLED device fabrication and a CIF file giving X-ray data for $\mathbf{1}$. This material is available free of charge via the Internet at http://pubs.acs.org.

OM0498246 